\title{
FREQUENCY OF LOW LEVELS OF HIGH DENSITY LIPOPROTEIN CHOLESTEROL IN PATIENTS WITH ACUTE CORONARY SYNDROME.
}

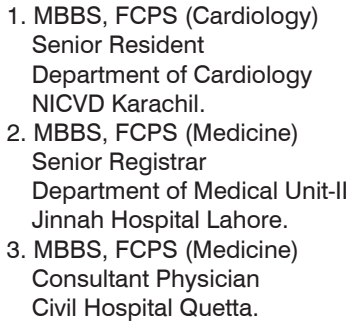

Correspondence Address: Dr. Tahir Ullah Khan Room No. 109, PG Doctors Hostel Shaikh Zayed Hospital Lahore. tahirnurar69@gmail.com

\section{Article received on:} 20/11/2018

Accepted for publication: 12/03/2019

Received after proof reading: 00/00/2019

\begin{abstract}
Muhammad Niaz Khan', Tahir Ullah Khan², Siraj Ud Din ${ }^{3}$
ABSTRACT... To find out frequency of low HDL-C levels in patients suffering from acute coronary syndrome. Study Design: Descriptive cross sectional study. Setting: Department of cardiology Khyber Teaching Hospital (KTH) Peshawar. Period: 04/04/2016 to 04/10/2016. Material \& Methods: By applying WHO formula for sample size calculation and $95 \%$ confidence interval, a total of 154 Patients admitted to coronary care unit (CCU) of Khyber Teaching Hospital with acute coronary syndrome were selected. Anticipated portion of low HDL in ACS was $73.3 \%$ and absolute precision of about $7 \%$. Results: In this study, mean age was $55.720 \pm 8.901$ years. About $38 \%$ patients were of female gender while $62 \%$ patients were male. About $20 \%$ patients had UA, $9 \%$ patients had NSTEMI, and $71 \%$ patients had STEMI. Patients with low high density lipoproteins constituted about $48 \%$ of the total patients admitted with ACS. Conclusion: Our study concluded that significant number $(48 \%)$ of patients with ACS had low HDL levels.
\end{abstract}

Key words: $\quad$ Acute Coronary Syndrome, High Density Lipoprotein Cholesterol.

Article Citation: Khan MN, Khan T, Siraj Ud Din. Frequency of low levels of High Density Lipoprotein cholesterol in patients with acute coronary syndrome. Professional Med J 2019; 26(12):2054-2057. DOI: 10.29309/TPMJ/2019.26.12.1364

\section{INTRODUCTION}

Acute coronary syndrome (ACS) is one of the deadly cardiac emergences comprising of unstable angina, non ST elevation myocardial infarction (NSTEMI) and ST elevation MI (STEMI), and is a life-threatening health issue around the globe. Although a considerable decrease in mortality due to ACS has been noted in recent times because of the better revascularization techniques and medications, but still it remains a major health hazard. According to WHO report in 2008, ischemic heart disease was responsible for 7.25 million deaths globally. ${ }^{1}$ The concept that high density lipoproteins may protect against coronary artery disease was proposed by numerous studies, indicating a strong association between low plasma HDL levels and increased risk of coronary artery disease, particularly in the pathogenesis of premature coronary atherosclerosis. ${ }^{2}$ Population-based studies state that for every $1 \mathrm{mg} / \mathrm{dl}$ decrease in high density lipoproteins cholesterol level, risk of future cardiovascular events increases by $2 \%$ to $3 \%{ }^{3}$
High density lipoproteins (HDL) are thought to have a pivotal role in reverse cholesterol transport (cholesterol efflux from cells) that in turn leads to inhibition of atherosclerosis progression. Additionally, HDL lipoproteins are vital for platelet activation, countering inflammation, oxidation, and optimal functioning of endothelium. ${ }^{4}$ Statins are lipid lowering medications used worldwide for dyslipidemias especially in those at high risk for cardiovascular disease. It is currently estimated that 1 of every 8 US adults is treated with lipidlowering therapy, mostly statins. Research have shown that higher the serum HDL levels, lower is the risk of cardiovascular events. In contrast to HDL having a protective role in coronary artery disease, Mora and colleagues found a negative correlation between high LDL values and coronary artery disease. ${ }^{5}$ Current study will provide us local data to acknowledge importance of the low serum HDL levels in patients presenting with acute coronary syndrome (ACS) and the results will be used for early detection and timely intervention to improve low levels of HDL-C through different pharmacological and non-pharmacological 
measures to reduce the incidence of ACS.

\section{MATERIALS AND METHODS}

The study was carried out in department of Cardiology, KTH Peshawar over a period of 6 months from 4/4/2016 to 4/10/2016. Sample size was about 154 as calculated by WHO formula. Confidence interval was selected as $95 \%$. Anticipated portion of low HDL in ACS was $73.3 \%$ and absolute precision was $7 \%$. Subjects entitled to be part of our study were those admitted to KTH CCU with acute coronary syndrome (ACS), regardless of the gender and age range of 18 to 70 years. Patients excluded from our study were those with chronic renal failure (creatinine $>2.5 \mathrm{mg} / \mathrm{dl}$ ) and those with multi organ failure and moribund patients such as respiratory failure, pneumonia, ketoacidosis, pulmonary embolism, hepatic encephalopathy, stroke. After approval from hospitals ethical committee and written informed consent from patients, data was collected as per our designed Performa.

All patients were subjected to detailed history and clinical examinations followed by necessary investigations e.g. ECG, Cardiac Enzymes and Lipid profile. SPSS version 23.0was used to analyze the data. Quantitative variables e.g. Age and HDL-C levels were measured as mean \pm SD. Qualitative variables like gender, STEMI, NSTEMI, Unstable Angina and low level of HDL-C were presented in the form of frequencies and percentages. In order to see effect modification, Outcome (low level of HDL-C) was stratified among gender and age using Chi square test.

\section{RESULTS}

Regarding distribution of patients according to age, mean age was $55.720 \pm 8.901$ years (Table-l). About $62 \%$ patients $(n=95)$ were male and $38 \%(n=59)$ were female (Table-II). Maximum number (54 patients, 35\%) of patients with ACS was between 61 to 70 years of age, while $51(33 \%)$ participants were in age range 51 to 60 years. About 38(25\%) participants aged between 41 to 50 years and $11(7 \%)$ patients aged between 30 to 40 years. Regarding the type of acute coronary syndrome, about $31(20 \%)$ patients had UA, 14(9\%) patients had NSTEMI, 109 (71\%) patients had STEMI (Table-III). About 74(48\%) patients had
Low level of HDL C, while $80(52 \%)$ patients had normal level of HDL C. (table-IV). Stratification of low serum HDL Cholesterol levels with age and gender is illustrated in Table-V,VI.

\begin{tabular}{|c|c|c|}
\hline Age Range & $\begin{array}{l}\text { Frequency (No } \\
\text { of Patients) }\end{array}$ & Percentage (\%) \\
\hline 61 to 70 years & 54 & $35 \%$ \\
\hline 51 to 60 years & 51 & $33 \%$ \\
\hline 41 to 50 years & 38 & $25 \%$ \\
\hline 30 to 40 years & 11 & $7 \%$ \\
\hline Total & 154 & 100 \\
\hline \multicolumn{3}{|c|}{$\begin{array}{l}\text { Table-I. Age Distribution }(n=154) \\
\text { Mean and SD age was } 55.720 \text { years } \pm 8.901\end{array}$} \\
\hline Gender & $\begin{array}{c}\text { Frequency } \\
\text { (No of Patients) }\end{array}$ & Percentage (\%) \\
\hline Female & 59 & $38 \%$ \\
\hline Male & 95 & $62 \%$ \\
\hline Total & 154 & 100 \\
\hline \multicolumn{3}{|c|}{ Table-II. Distribution of Patients According to Gender } \\
\hline Type of ACS & Frequency & Percentage (\%) \\
\hline Unstable Angina & 31 & $20 \%$ \\
\hline NSTEMI & 14 & $9 \%$ \\
\hline STEMI & 109 & $71 \%$ \\
\hline Total & 154 & 100 \\
\hline
\end{tabular}

Table-III. Type of Acute Coronary Syndrome $(n=154)$

\begin{tabular}{|l|c|c|}
\hline \multicolumn{1}{|c|}{$\begin{array}{c}\text { Low HDL C } \\
\text { levels }\end{array}$} & Frequency & Percentage (\%) \\
\hline Yes & 74 & $48 \%$ \\
\hline No & 80 & $52 \%$ \\
\hline Total & 154 & 100 \\
\hline
\end{tabular}

Table-IV. Low Levels of HDL Cholesterol $(n=154)$

\begin{tabular}{|l|c|c|c|c|c|}
\hline $\begin{array}{l}\text { Low level } \\
\text { of HDL C }\end{array}$ & $\begin{array}{c}\mathbf{3 0 - 4 0} \\
\text { years }\end{array}$ & $\begin{array}{c}\mathbf{4 1 - 5 0} \\
\text { years }\end{array}$ & $\begin{array}{c}\mathbf{5 1 - 6 0} \\
\text { years }\end{array}$ & $\begin{array}{c}\mathbf{6 1 - 7 0} \\
\text { years }\end{array}$ & Total \\
\hline Yes & 5 & 19 & 24 & 26 & 74 \\
\hline No & 6 & 19 & 27 & 28 & 80 \\
\hline Total & 11 & 38 & 51 & 54 & 154 \\
\hline
\end{tabular}

Table-V. Stratification of Low HDL-C Levels W.R.T Age Distribution $(n=154)$

\begin{tabular}{|l|c|c|c|}
\hline $\begin{array}{l}\text { Low level } \\
\text { of HDL C }\end{array}$ & Male & Female & Total \\
\hline Yes & 46 & 28 & 74 \\
\hline No & 49 & 31 & 80 \\
\hline Total & 95 & 59 & 154 \\
\hline \multicolumn{2}{|c|}{ Table-VI. Stratification of Low HDL-C Levels W.R.T. } \\
Gender Distribution (n=154)
\end{tabular}




\section{DISCUSSION}

Low HDL levels have been considered to be an important risk factor for development of cardiovascular disease. Mean age of our study population was $55.720 \pm 8.90$ years with 62 $\%$ male and $38 \%$ female. About $20 \%$ patients had UA, $9 \%$ patients had NSTEMI, and $71 \%$ patients had STEMI. About $48 \%$ patients had Low level of HDL-C. Similar findings were observed in another study conducted by Bhalli $\mathrm{MA}^{6}$ in which 106 (78.5\%) had total cholesterol (TC) levels < 200 $\mathrm{mg} / \mathrm{dl}$, while 29 (21.4\%) had TC above $200 \mathrm{mg} /$ dl. LDL cholesterol (LDL-C) below $100 \mathrm{mg} / \mathrm{dl}$ was seen in 81 (60\%), remaining had LDL-C > 100 $\mathrm{mg} / \mathrm{dl}$. HDL cholesterol was below $40 \mathrm{mg} / \mathrm{dl}$ in 41 (30.4\%). Triglycerides (TG) were below $150 \mathrm{mg} /$ dl in 59 (43.7\%) persons while levels above 250 $\mathrm{mg} / \mathrm{dl}$ were seen in 10 (7.3\%). Total cholesterolto-HDL ratio (TC/HDL) above 5 was seen in 21 (15.5\%) patients. In other study conducted by Pintó $X^{7}$, about $56.6 \%$ (367) patients with ACS were found to have Low HDL-C (defined as serum HDL-C < $1.04 \mathrm{mmol} / \mathrm{L}$ ), slightly higher than our results. Factors leading to low HDL-C were smoking, raised blood pressure, male gender, diabetes mellitus, high body mass index, hypertriglyceridemia and previous history of ischemic heart disease.

According to observations of Khalid Al-Rasad and his colleagues ${ }^{8}$, approximately $62 \%$ of ACS patients had low HDL-cholesterol levels. The strongest contributors to low HDL-C noted in this study were smoking, diabetes mellitus, morbid obesity, previous cardiac event and renal dysfunction. After making multivariable adjustments, it was noted that low HDL-C was also an important contributing factor to cardiovascular deaths ((OR), 1.54; 95\% Cl: 1.06-2.24; $p=0.022)$ and cardiogenic shock (OR, 1.61; 95\% Cl: 1.202.14; $p=0.001)$.

\section{CONCLUSION}

It was concluded from our study that the frequency of low levels of high density lipoprotein cholesterol
(HDL-C) was found to be $48 \%$ in patients presenting with acute coronary syndrome.

Copyright@ 12 March, 2019.

\section{REFERENCES}

1. Thabetlbrahim N, Hassanin AhmadH, Kamal Mohammad Y. Study of high density lipoprotein cholesterol among patients with acute coronary syndrome in Sohag University Hospital. J CardiolCurrRes 2015, 2(5): 00073

2. Christian B, Thomas F. Lüscher, Landmesser F. Molecular mechanisms of vascular effects of high $\square$ density lipoprotein: Alterations in cardiovascular disease. EMBO molecular medicine.2012; 4.4: 251-2

3. Acharjee S, William E. Boden, Pamela M et al. Low levels of high-density lipoprotein cholesterol and increased risk of cardiovascular events in stable ischemic heart disease patients: A post-hoc analysis from the COURAGE Trial (Clinical Outcomes Utilizing Revascularization and Aggressive Drug Evaluation). J Am CollCardiol 62.20 (2013); 1826-1833

4. Parin J Patel,Amit V Khera, Jafri K, Robert L Wilensky, Daniel J Rader. The anti-oxidative capacity of highdensity lipoprotein is reduced in acute coronary syndrome but not in stable coronary artery disease. J Am CollCardiol58.20 (2011); 2068-2075.

5. Mora S, Nanette K Wenger, David A DeMicco, Breazna $A$, et al. Determinants of residual risk in secondary prevention patients treated with high-versus lowdose statin therapy the treating to new targets (TNT) study. Circulation 125.16 (2012); 1979-1987.

6. Bhalli MA, Kayani AM, Samore NA. Frequency of risk factors in male patients presenting with acute coronary syndrome. J CPSP. 2011, Vol. 21 (5): 271275.

7. Pintó X1, Millán J, Muñoz A, Corbella E, HernándezMijares A, Zuñiga M, Mangas A, Pedro-Botet J. A very high prevalence of low HDL cholesterol in Spanish patients with acute coronary syndromes. Clin Cardiol. 2010 Jul; 33(7):418-23

8. Al-Rasadi K,, Al-Zakwani I, Zubaid M, Ali A, Bahnacy $\mathrm{Y}$, Prevalence, predictors, and impact of low highdensity lipoprotein cholesterol on in-hospital outcomes among acute coronary syndrome patients in the middle east. Open Cardiovasc Med J. 2011; 5: 203-209. 


\title{
Birds born in a cage think flying in a illness.
}

\author{
"Alejando Jodorowski"
}

\begin{tabular}{|c|c|c|c|}
\hline \multicolumn{3}{|c|}{ AUTHORSHIP AND CONTRIBUTION DECLARATION } \\
\hline Sr. \# & Author(s) Full Name & \multicolumn{1}{|c|}{ Contribution to the paper } & Author(s) Signature \\
\hline 1 & Muhammad Niaz Khan & $\begin{array}{l}\text { Hypothesis designing, Data } \\
\text { collection, article allangment } \\
\text { and finalization. } \\
\text { Statistical analysis manuscript } \\
\text { preparation \& design, } \\
\text { References style, Tables \& } \\
\text { figures. } \\
\text { Proof reading, Final Review. }\end{array}$ \\
\hline
\end{tabular}

